\title{
Annual Manufacturing Review
}

Douglas S. Thomas Anand M. Kandaswamy

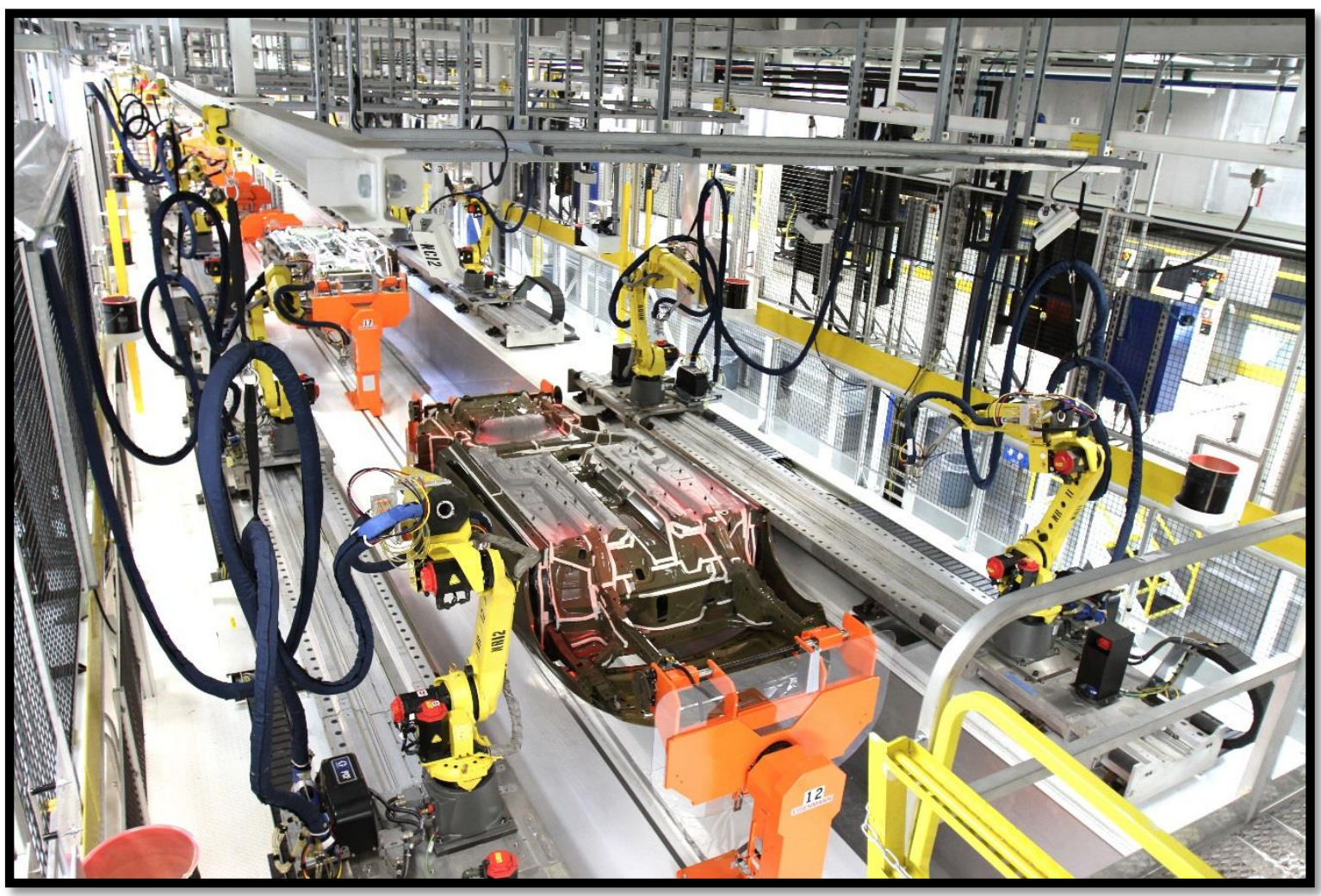

This publication is available free of charge from: http://dx.doi.org/NIST.TN.1901

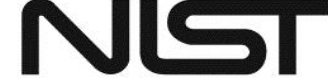

National Institute of Standards and Technology U.S. Department of Commerce 



\title{
NIST Technical Note 1901
}

\section{Annual Manufacturing Review}

\author{
Douglas S. Thomas \\ Anand M. Kandaswamy \\ Applied Economics Office \\ Engineering Laboratory
}

This publication is available free of charge from:

http://dx.doi.org/NIST.TN.1901

November 2015

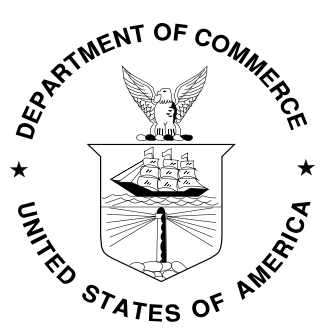

U.S. Department of Commerce Penny Pritzker, Secretary

National Institute of Standards and Technology Willie E. May, Under Secretary of Commerce for Standards and Technology and Director of NIST 
Certain commercial entities, equipment, or materials may be identified in this document in order to describe an experimental procedure or concept adequately. Such identification is not intended to imply recommendation or endorsement by the National Institute of Standards and Technology, nor is it intended to imply that the entities, materials, or equipment are necessarily the best available for the purpose.

National Institute of Standards and Technology Technical Note 1901 Natl. Inst. Stand. Technol. Tech. Note 1901, 38 pages (November 2015)

CODEN: NTNOEF This publication is available free of charge from: http://dx.doi.org/10.6028/NIST.TN.1901 


\section{Abstract}

This report provides an overview of the US manufacturing industry. There are three aspects of U.S. manufacturing that are considered: (1) how the US industry compares to other countries, (2) the trends in the domestic industry, and (3) the industry trends compared to other country's trends. According to the 2013 Annual Survey of Manufactures (ASM), the US manufacturing sector produced $\$ 2.4$ trillion in value added in 2013 , up $4.2 \%$ from $\$ 2.3$ trillion in 2012 . Value added in machinery manufacturing (North American Industry Classification System code (NAICS) 333), computer and electronic product manufacturing (NAICS 334), electrical equipment (NAICS 335), and transportation equipment (NAICS 336) grew $1.1 \%, 10.0 \%, 0.0 \%$, and $6.1 \%$, respectively. According to data from the United Nations Statistics Division, US compound annual real (controlling for inflation) growth between 1988 and 2013 was $2.2 \%$. This puts the US in the $47^{\text {th }}$ percentile of all countries. This growth exceeded that of Germany, France, Canada, Japan, and Australia; however, it is slower than the global average and that of many emerging economies. The size of the US manufacturing industry, as measured in value added, remains the largest of all countries. Among the ten largest manufacturing countries, the US has the $4^{\text {th }}$ largest manufacturing value added per capita.

Keywords: durable goods, economic accounts, manufacturing, value added, employment 


\section{Preface}

This study was conducted by the Applied Economics Office (AEO) in the Engineering Laboratory (EL) at the National Institute of Standards and Technology (NIST). The study provides aggregate manufacturing industry data and industry subsector data to develop a quantitative depiction of the U.S. manufacturing industry.

\section{Disclaimer}

Certain trade names and company products are mentioned in the text in order to adequately specify the technical procedures and equipment used. In no case does such identification imply recommendation or endorsement by the National Institute of Standards and Technology, nor does it imply that the products are necessarily the best available for the purpose.

\section{Cover Photographs Credits}

At the Paint Shop in Chrysler Group's Sterling Heights (Mich.) Assembly Plant, a 2015 Chrysler 200 moves through the Underbody Sealing and Underbody Coating station, flipping the vehicle body completely upside down to seal all appropriate seams and compartments. (2014). This image was used in accordance with Fiat Chrysler Automobile's editorial use policy. 


\section{Acknowledgements}

The authors wish to thank all those who contributed so many excellent ideas and suggestions for this report. Special appreciation is extended to Simon Frechette, Katherine Morris, and Dr. Vijay Srinivasan of EL's Systems Integration Division for their technical guidance, suggestions, and support. Special appreciation is also extended to Dr. Robert Chapman and Dr. Joshua Kneifel of EL's AEO and to David Pitchure of MML's Mechanical Performance Group for their thorough reviews and many insights. The author also wishes to thank Dr. Nicos Martys, of the Materials and Structural Systems Division for his review. 


\section{Table of Contents}

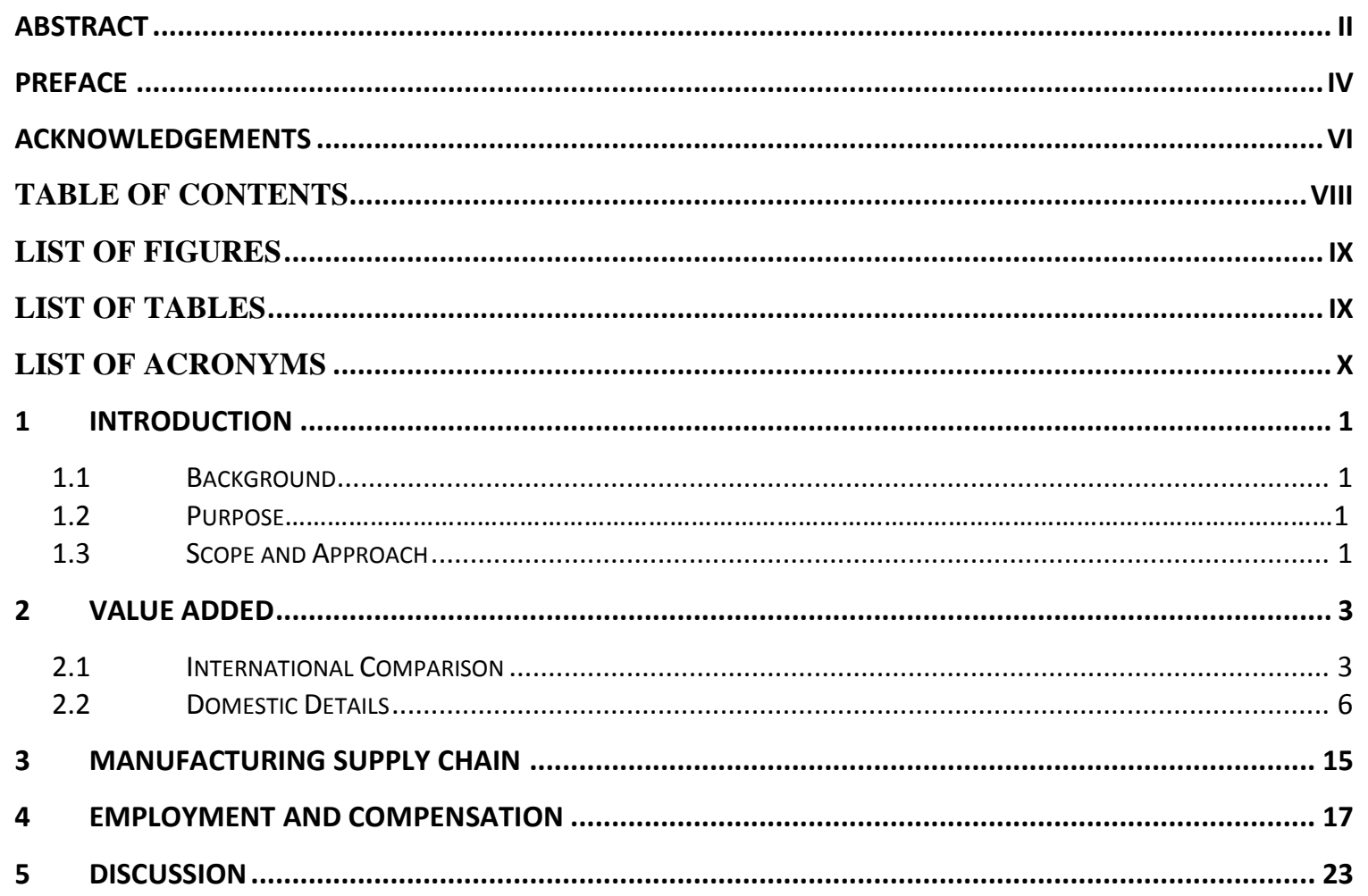




\section{List of Figures}

Figure 2-1: 25 Year Compound Annual Growth (1988 to 2013) .................................... 4

Figure 2-2: 5 Year Compound Annual Growth (2008 to 2013) ....................................... 4

Figure 2-3: Manufacturing Value Added, Top 10 Manufacturing Countries (1970 to

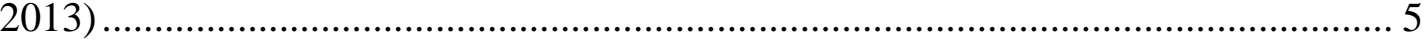

Figure 2-4: Manufacturing Value Added Per Capita, Top 10 Manufacturing Countries

(1970 to 2013)............................................................................................................ 6

Figure 2-5: Cumulative Percent Change in Value Added (2009 Chained Dollars).......... 11

Figure 2-6: Value Added for Durable Goods by Type, 2006-2013 ............................... 12

Figure 2-7: Value Added for Nondurable Goods by Type, 2006-2013 ......................... 12

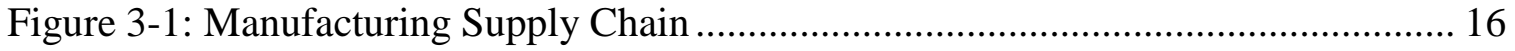

Figure 4-1: Cumulative Change in Percent in Manufacturing Employment (Seasonally

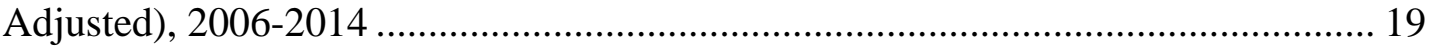

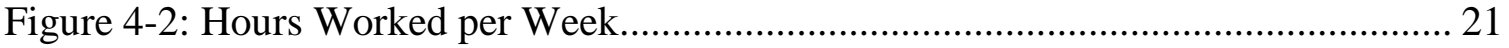

Figure 4-3: Wages for Manufacturing and Private Industry ....................................... 21

\section{List of Tables}

Table 2-3: Manufacturing Activity by Economic Measure by Subsector ........................ 7

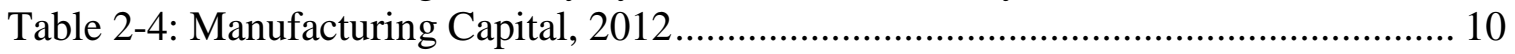

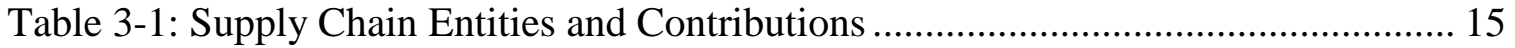

Table 4-1: Employment, Annual Survey of Manufactures ........................................... 17

Table 4-2: Employment by Industry for 2013 and 2014 (Thousands): Current Population

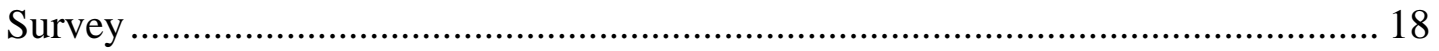

Table 4-3: Manufacturing Employment (Thousands): Current Employment Statistics ... 18

Table 4-4: Fatal Occupational Injuries by Event or Exposure ......................................... 20

Table 4-5: Total Recordable Cases of Nonfatal Injuries and Illnesses, Private Industry . 20 


\section{List of Acronyms}

ASM: Annual Survey of Manufactures

BEA: Bureau of Economic Analysis

GDP: Gross Domestic Product

IBRD: International Bank for Reconstruction and Development

IDA: International Development Association

ISIC: International Standard Industrial Classification

MAPI: Manufacturers Alliance for Productivity and Innovation

NAICS: North American Industry Classification System

NIST: National Institute of Standards and Technology

PPP: Purchasing Power Parity

SIC: Standard Industrial Classification

UNSD: United Nations Statistics Division 


\section{Introduction}

\subsection{Background}

Manufacturing industry change agents, who are entities that invest in advancing the current state of the industry, have a need to understand the recent activities in manufacturing. Access to high quality data about manufacturing is crucial for such analysis. However, economic data on manufacturing is disjointed and scattered among various sources, and no single source can claim to capture all the relevant data. This makes it difficult to quickly and accurately assess the recent activities and trends in the industry.

\subsection{Purpose}

The purpose of this report is to track domestic manufacturing activity in order to develop a quantitative depiction of U.S. manufacturing in the context of the domestic economy and global industry. This depiction provides change agents, who invest in advancing the current state of manufacturing, insight into the current state and recent trends in US manufacturing.

\subsection{Scope and Approach}

There are numerous aspects one could examine in manufacturing. This report discusses a subset of stakeholders and focuses on US manufacturing. Among the many datasets available, it utilizes those that are prominent and are consistent with economic standards. These boundaries are further discussed below.

Stakeholders: Stakeholders are those entities that contribute resources to the industry and/or receive a form of benefit from industry activity. It could be the stakeholder is a consumer of a manufactured product, a producer, or a party that is financing the manufacturing itself; all that is required for a stakeholder classification is that the entity is materially affected by the industry.

Each stakeholder is associated with a primary form of investment. For example, employees invest their labor while owners invest land, capital, labor, and/or intellectual property. Consumers invest their scarce resources into the purchase of manufactured goods. For members of the general public who do not act as consumers, the manufacturing process can still affect them through the existence of externalities, like air or water pollution from the manufacturing process. This report focuses on the employees and the owners/investors, as the data available facilitates examining these entities. Future work may move toward examining other stakeholders in manufacturing, such as the consumers and general public.

Geographic Scope: Many change agents are concerned with a certain group of people or organizations. Since NIST is concerned with "US innovation and competitiveness," this report focuses on activities within the national borders. In a world of globalization, this effort is challenging, as some of the parts and materials being used in US manufacturing 
activities are imported. The imported values are a relatively small percentage of the total activity. In terms of 2009 imported supply chain value added used by a nation's manufacturing industry as a percent of all value added associated with that nation's manufacturing industry, the U.S. imported $10.8 \%$ of its supply chain. ${ }^{1}$ These imports have environmental impacts, require natural resources, and utilize labor; thus, they are important in regards to a firm's production. NIST, however, promotes US innovation and industrial competitiveness; therefore, the imported goods and services are outside of the scope of this report.

Standard Data Categorization: US Domestic data tends to be organized using the NAICS, which is the standard used by Federal statistical agencies classifying business establishments in the U.S. NAICS was jointly developed by the U.S. Economic Classification Policy Committee, Statistics Canada, and Mexico's Instituto Nacional de Estadística y Geografía, and was adopted in 1997. NAICS has several major categories each with subcategories. Historic data and some organizations continue to use the predecessor of NAICS, which is the Standard Industrial Classification system (SIC). NAICS codes are categorized at varying levels of detail. The broadest level of detail is the two digit NAICS code, which has 20 categories. More detailed data is reported as the number of digits increases; thus, three digits provide more detail than the two digit and the four digit provides more detail than the three digit. The maximum is six digits. Sometimes a two, three, four, or five digit code is followed by zeros, which do not represent categories. They are null or place holders. For example, the code 336000 represents NAICS 336. International data tends to be in the International Standard Industrial Classification (ISIC) version 3.1, a revised United Nations system for classifying economic data. Manufacturing is broken into 23 major categories (ISIC 15 through 37) with additional subcategories. This data categorization works similar to NAICS in that additional digits represent additional detail.

Data Sources: Thomas (2012) explores a number of data sources for examining US manufacturing activity. ${ }^{2}$ This report selects from sources that are the most prominent and reveal the most information about the US manufacturing industry. These data include the United Nations Statistics Division's National Accounts Main Aggregates Database and the US Census Bureau's Annual Survey of Manufactures, among others. ${ }^{3}$ Because the data sources are scattered across several resources, there are differences in what yearly data is available for a particular category or topic. In each case, the most-up-to-date and available information is provided for the relevant category.

\footnotetext{
${ }^{1}$ Thomas, Douglas S. The US Manufacturing Value Chain: An International Perspective. February 2014. NIST Technical Note 1810. <http://www.nist.gov/customcf/get_pdf.cfm?pub_id=914022>

2 Thomas, Douglas S. The Current State and Recent Trends of the US Manufacturing Industry. NIST Special Publication 1142. <http://nvlpubs.nist.gov/nistpubs/SpecialPublications/NIST.SP.1142.pdf>

${ }^{3}$ See <http://unstats.un.org/unsd/snaama/dnlList.asp > and <http://www.census.gov/manufacturing/asm/>
} 


\section{Value Added}

Value added is the primary measure of economic activity. It is the increase in the value of output at a given stage of production; that is, it is the value of output minus the cost of inputs from other firms. ${ }^{4}$ The primary elements that remain after subtracting inputs is taxes, compensation to employees, and gross operating surplus; thus, the sum of these also equal value added. Gross operating surplus is used to calculate profit, which is gross operating surplus less the depreciation of capital such as buildings and machinery. The sum of all value added for a country is that nation's Gross Domestic Product (GDP).

\subsection{International Comparison}

There are a number of sources of international estimates of value added for manufacturing. The United Nations Statistics Division National Accounts Main Aggregates Database has a very complete dataset that covers a large number of countries over a significant period of time. According to this data, in 2013, there was $\$ 9.5$ trillion in value added (i.e. GDP) by global manufacturing, which is $18 \%$ ( $\$ 53.7$ trillion) of the value added by all industries, according to the United Nations Statistics Division. The top 5 manufacturing countries accounted for $\$ 5.5$ trillion or $57.6 \%$ of manufacturing value added: United States (18.8 \%), China (18.5\%), Japan (10.5\%), Germany (7.0 \%), and France $(2.8 \%)$ (UNSD 2015). ${ }^{5}$

As seen in Figure 2-1, US compound real (controlling for inflation) annual growth between 1988 and 2013 was $2.2 \%$, which places the US in the $47^{\text {th }}$ percentile of all countries. This growth exceeded that of Germany, France, Canada, Japan, and Australia; however, it is slower than the global average (3\%) and that of many emerging economies. It is important to note that emerging economies can employ idle or underutilized resources and adopt technologies that are already proven in other nations to achieve high growth rates. Developed countries are already utilizing resources and are employing advanced technologies; thus, comparing U.S. growth to the high growth rates in China or India has limited meaning. As seen in Figure 2-2, the compound annual growth for the US between 2008 and 2013 was $-0.1 \%$. This puts the US at the $29^{\text {th }}$ percentile below France and Germany but still above that of Japan and Australia.

As seen in Figure 2-3, the size of the US manufacturing industry, as measured in value added, remains the largest of all countries, slightly above China and well above all other countries. Among the ten largest manufacturing countries, the US is the $4^{\text {th }}$ largest manufacturing value added per capita, as seen in Figure 2-4. It is important to note, however, that there are varying means for adjusting data. Some methods show China as being the largest while others show the US being the largest. The UNSD data uses market exchange rates while others might use purchasing power parity (PPP) exchange rates.

\footnotetext{
${ }^{4}$ Dornbusch, Rudiger, Stanley Fischer, adn Richard Startz. 2000. Macroeconomics. 8th ed. London, UK: McGraw-Hill.

${ }^{5}$ United Nations Statistics Division. "National Accounts Main Aggregates Database."

<http://unstats.un.org/unsd/snaama/Introduction.asp>
} 
Figure 2-1: National 25 Year Compound Annual Growth, by Country (1988 to 2013)

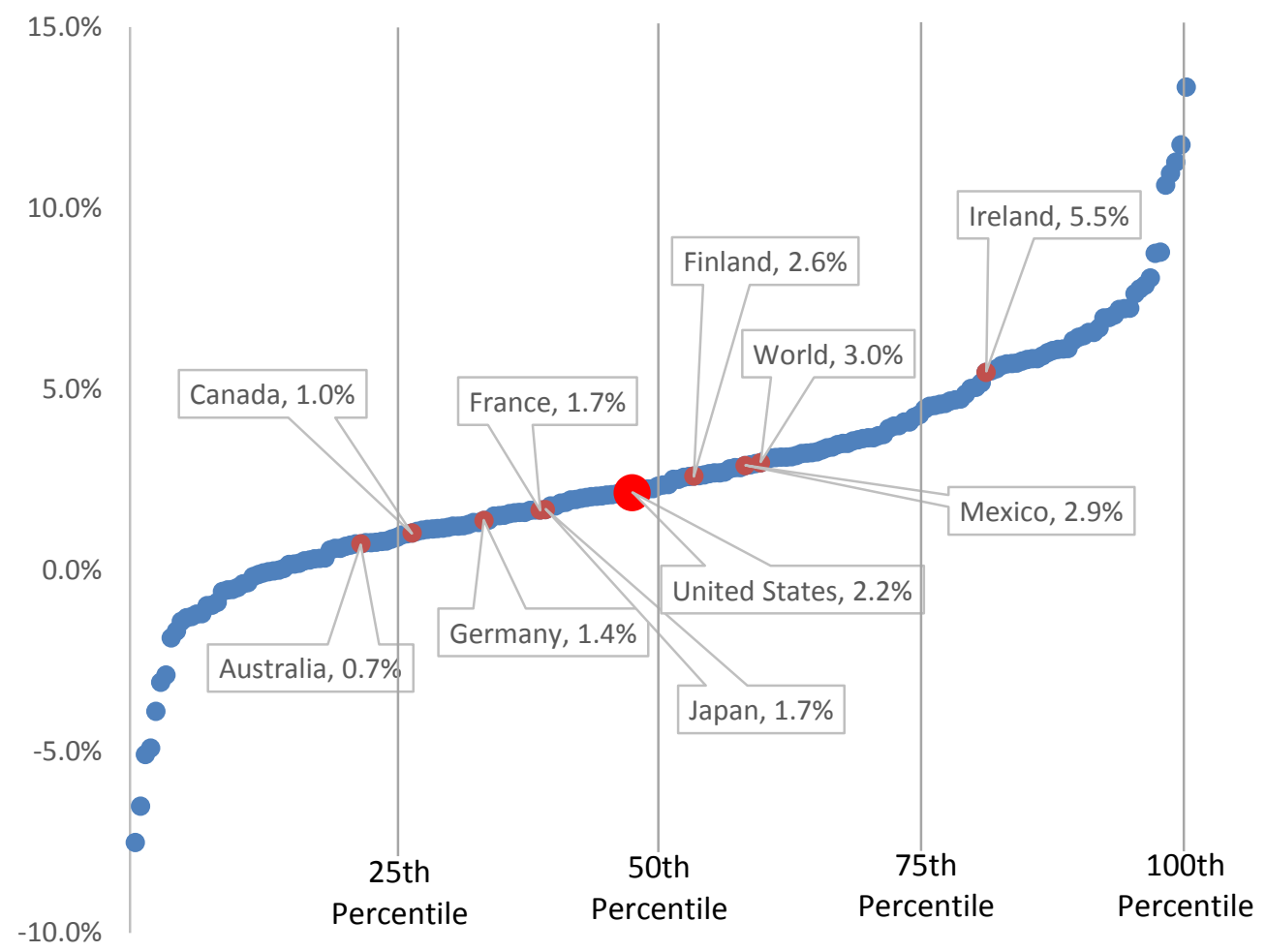

Figure 2-2: National 5 Year Compound Annual Growth, by Country (2008 to 2013)

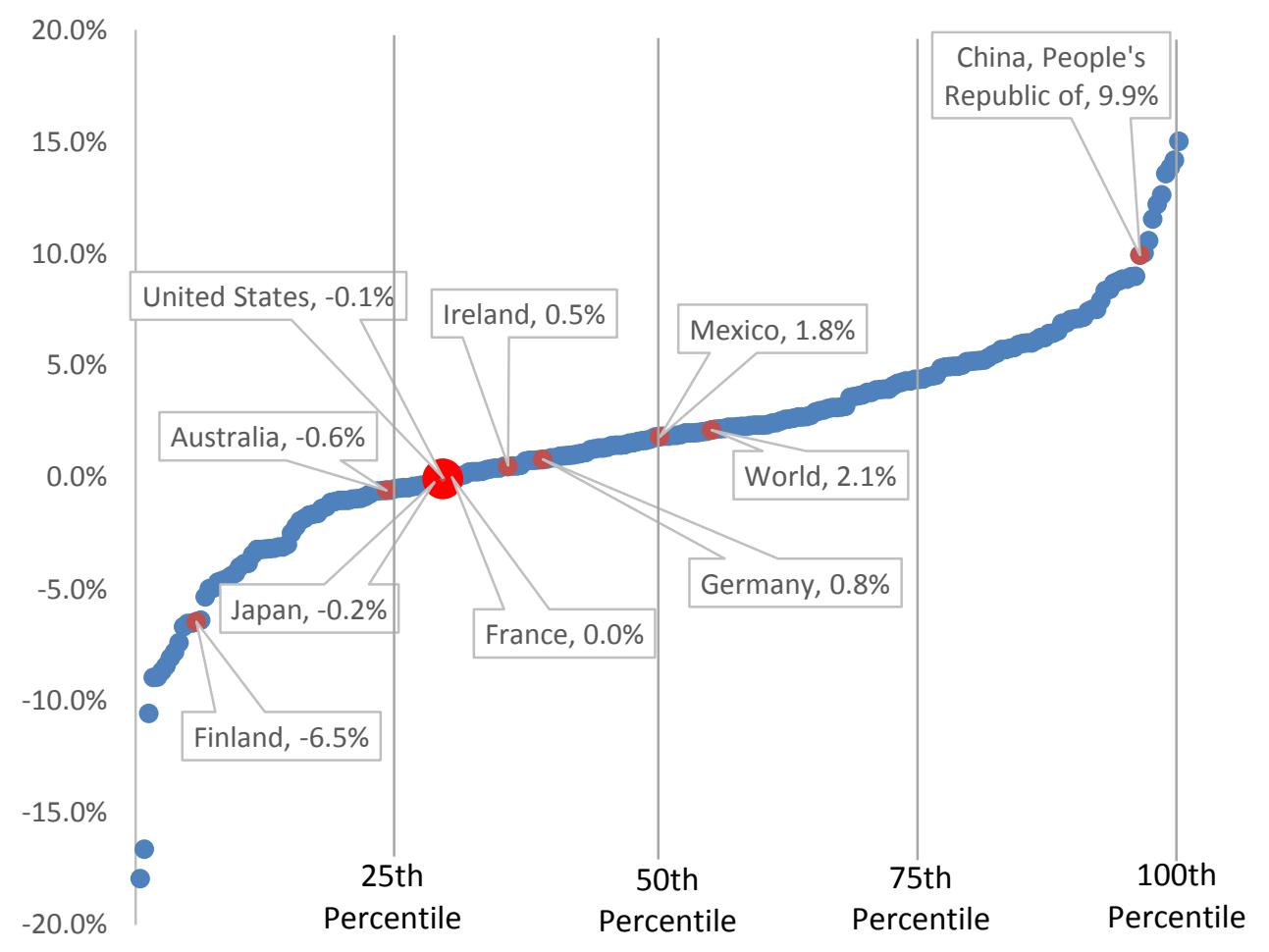


PPP is the rate that a currency in one country would have to be converted to purchase the same goods and services in another country. The drawback of PPP is that it is difficult to measure and methodological questions have been raised about some surveys that collect data for these calculations. ${ }^{6}$ Market based rates tend to be relevant for internationally traded goods ${ }^{7}$; therefore, this report utilizes these rates.

Additional data collected by the International Bank for Reconstruction and Development (IBRD) and the International Development Association (IDA) at the World Bank, shows manufacturing (defined for World Bank purposes as belonging to ISIC divisions 15-37) added $12 \%$ value to U.S. GDP in 2013, the most recent year for which the statistic is available. This is only slightly less than its $13 \%$ contribution to American GDP for each of the previous 3 years. Going back to 2000 in the World Bank statistics, manufacturing's contribution to GDP has varied within a fairly narrow band between $12 \%$ and $16 \%$. Thus manufacturing's contribution to GDP has remained fairly stable in this millennium, even as the United States emerges from a serious recession. For comparison's sake, Thailand was the category leader in 2013 with $33 \%$ value added to GDP from manufacturing. The United States falls roughly in the middle of the country rankings, which is not surprising for an advanced economy. ${ }^{8}$

Figure 2-3: Manufacturing Value Added, Top 10 Manufacturing Countries (1970 to 2013)

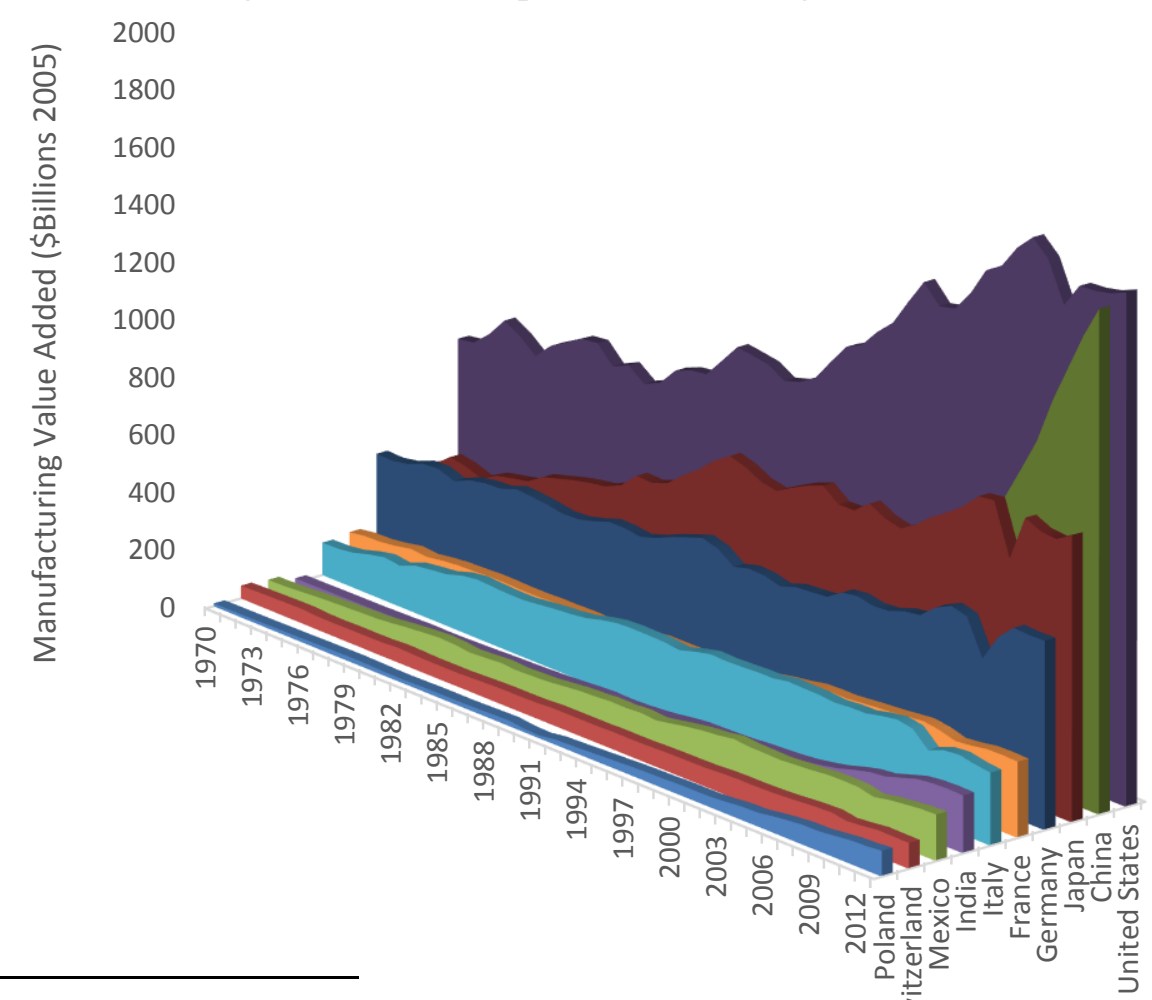

\footnotetext{
${ }^{6}$ Callen, Tim. March 2007. PPP Versus the Market: Which Weight Matters Finance and Development. Vol 44 number 1. 〈http://www.imf.org/external/pubs/ft/fandd/2007/03/basics.htm>

${ }^{7}$ Ibid.

${ }^{8}$ See World Bank Data at <http://data.worldbank.org/indicator/NV.IND.MANF.ZS>
} 
Figure 2-4: Manufacturing Value Added Per Capita, Top 10 Manufacturing Countries (1970 to 2013)

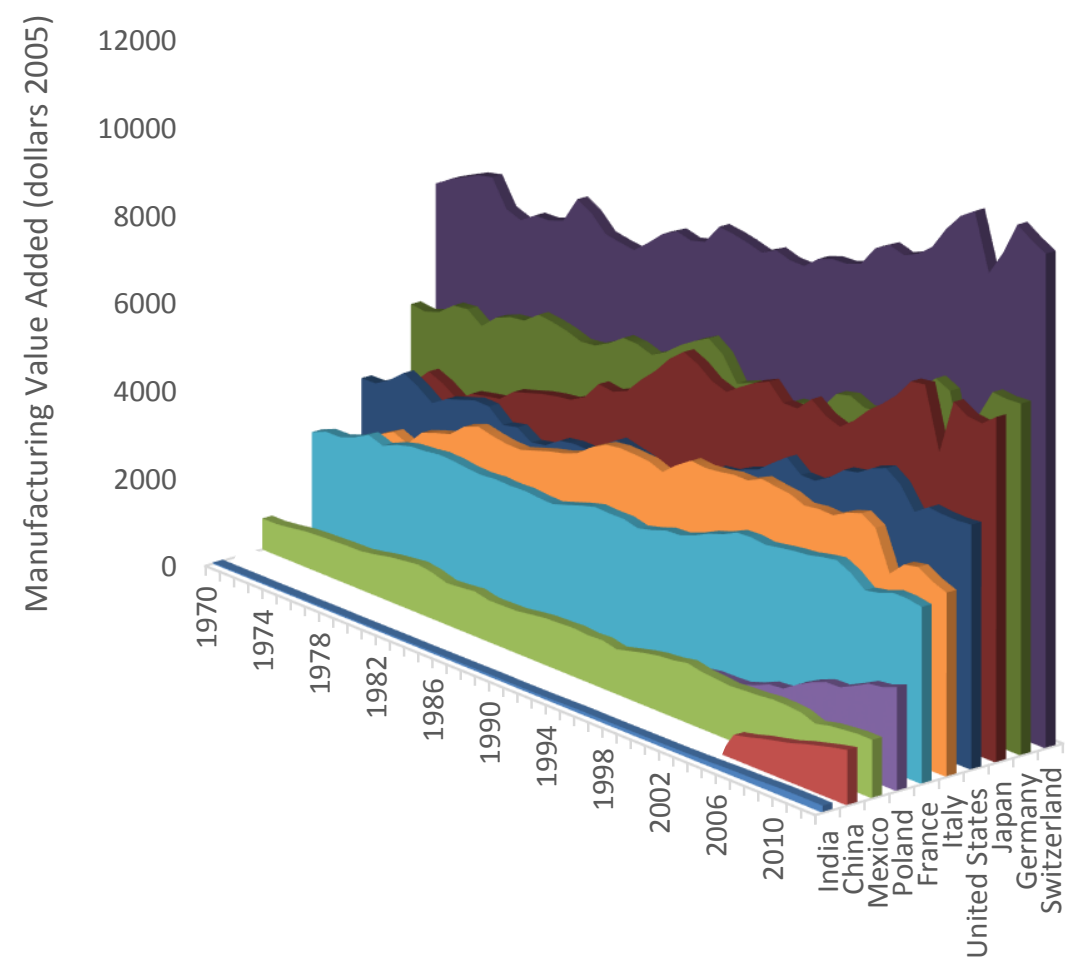

\subsection{Domestic Details}

Annual Survey of Manufactures: According to the 2013 Annual Survey of Manufactures (ASM) data shown in Table 2-1, the manufacturing sector produced \$2 398 billion in value added in 2013, up $4.2 \%$ from $\$ 2301$ billion in $2012 .{ }^{9}$ Value added in machinery manufacturing (NAICS 333), computer and electronic product manufacturing (NAICS 334), electrical equipment (NAICS 335), and transportation equipment (NAICS 336) grew $1.1 \%, 10.0 \%, 0.0 \%$, and $6.1 \%$ respectively. Shipments increased $2.6 \%$ over the same period to a total of $\$ 5847$ billion. The ASM calculation of value added is equal to the value of shipments less the cost of materials, supplies, containers, fuel, purchased electricity, and contract work. It is adjusted by the addition of value added by merchandising operations plus the net change in finished goods and work-in-process goods:

ASM Value Added = shipments - net inventories shipped suppliers of materials + merchandising operations

\footnotetext{
${ }^{9}$ Census Bureau. "Annual Survey of Manufactures.” February 2015. Accessed from the American FactFinder. <http://factfinder.census.gov/faces/nav/jsf/pages/index.xhtml> and Census Bureau. "Economic Census." March 2015. Accessed from the American FactFinder.

$<$ http://factfinder.census.gov/faces/nav/jsf/pages/index.xhtml>
} 
Value added avoids the duplication caused from the use of products of some establishments as materials. It is important to note that the Bureau of Economic Analysis (BEA) and the ASM calculate value added differently. The BEA, which follows the more

Table 2-1: Manufacturing Activity by Economic Measure by Subsector

2012

(\$Billions 2012)
2013

(\$Billions 2013)
Percent

Change

Manufacturing Shipments and Value Added

a. TOTAL MANUFACTURING

i. Net Inventories Shipped

ii. Depreciation of Capital

iii. Net Income

iv. Expenditures

a. Suppliers of Materials

v. Shipments $(\mathbf{i}+\mathbf{i i}+\mathbf{i i i}+\mathbf{i v})$

vi. ASM Value Added = v - i - iv.a + adjustment[1]

vii. Value Added = v - i - iv + Compensation [2]

viii. BEA Value Added
$-11.64$

181.90

780.68

4745.78

3407.06

5696.73

2300.72

1736.20

1829.50

b. NAICS 324: Petroleum \& coal products mfg

i. Net Inventories Shipped

ii. Depreciation of Capital

iii. Net Income

iv. Expenditures

a. Suppliers of Materials

v. Shipments $(\mathbf{i}+\mathbf{i i}+\mathbf{i i i}+\mathbf{i v})$

vi. ASM Value Added = v - i - iv.a + adjustment

vii. Value Added = v - i - iv + Compensation

c. NAICS 325: Chemical mfg

i. Net Inventories Shipped

ii. Depreciation of Capital

iii. Net Income

iv. Expenditures

a. Suppliers of Materials

v. Shipments $(\mathbf{i}+\mathbf{i i}+\mathbf{i i i}+\mathbf{i v})$

vi. ASM Value Added = v - i - iv.a + adjustment

vii. Value Added = v - i - iv + Compensation

d. NAICS 326: Plastics \& rubber products mfg

i. Net Inventories Shipped

ii. Depreciation of Capital

iii. Net Income

iv. Expenditures

a. Suppliers of Materials

v. Shipments $(\mathbf{i}+\mathbf{i i}+\mathbf{i i i}+\mathbf{i v})$

vi. ASM Value Added = v - i - iv.a + adjustment

vii. Value Added = v - i - iv + Compensation
0.03

10.92

71.40

768.79

719.58

851.14

131.53

95.14

1.44

30.21

188.84

564.80

419.07

785.30

364.78

289.01

$-0.87$

9.47

24.53

185.45

119.25

218.57

100.19

74.31

$\begin{array}{rr}-8.47 & 27.2 \% \\ \mathrm{a} & - \\ \mathrm{a} & - \\ 4826.39 & 1.7 \% \\ 3456.98 & 1.5 \% \\ \mathbf{5 8 4 6 . 7 7} & \mathbf{2 . 6 \%} \\ \mathbf{2 3 9 8 . 3 9} & 4.2 \% \\ 1817.90 & 4.7 \% \\ 1922.90 & 5.1 \%\end{array}$

$-0.60$

$-2302.5 \%$

$\mathrm{a}$
788.26

733.09

865.69

133.25

91.23

$-1.15$

$-179.9 \%$

$2.5 \%$

$1.9 \%$

$1.7 \%$

$1.3 \%$

$-4.1 \%$

568.05

423.46

$\mathbf{7 9 7 . 8 3}$

375.91

300.07

$$
-0.75
$$

$\mathrm{a}$

192.99

123.14

227.10

104.70

76.42
$14.5 \%$

$4.1 \%$

$3.3 \%$

$3.9 \%$

$4.5 \%$

$2.8 \%$ 
2012

(\$Billions 2012)

$-0.17$

7.61

8.97

82.64

44.91

99.04

54.31

38.00

vii. Value Added $=v-i$ - iv + Compensation
2013

(\$Billions 2013)

Percent

Change

\section{f. NAICS 331: Primary metal mfg}

i. Net Inventories Shipped

ii. Depreciation of Capital

iii. Net Income

iv. Expenditures

$$
\text { a. Suppliers of Materials }
$$

v. Shipments $(\mathbf{i}+\mathrm{ii}+\mathrm{iii}+\mathrm{iv})$

vi. ASM Value Added = v - i - iv.a + adjustment vii. Value Added = v - i - iv + Compensation

g. NAICS 332: Fabricated metal product mfg

i. Net Inventories Shipped

ii. Depreciation of Capital

iii. Net Income

iv. Expenditures

$$
\text { a. Suppliers of Materials }
$$

v. Shipments $(i+i i+i i i+i v)$

vi. ASM Value Added = v - i - iv.a + adjustment vii. Value Added = v - i - iv + Compensation

h. NAICS 333: Machinery mfg

i. Net Inventories Shipped

ii. Depreciation of Capital

iii. Net Income

iv. Expenditures

$$
\text { a. Suppliers of Materials }
$$

v. Shipments $(i+i i+i i i+i v)$

vi. ASM Value Added = v - i - iv.a + adjustment vii. Value Added = v - i - iv + Compensation

i. NAICS 334: Computer \& electronic product mfg

i. Net Inventories Shipped

ii. Depreciation of Capital

iii. Net Income

iv. Expenditures

$$
\text { a. Suppliers of Materials }
$$

v. Shipments $(\mathbf{i}+\mathbf{i i}+\mathbf{i i i}+\mathbf{i v})$

vi. ASM Value Added = v - i - iv.a + adjustment vii. Value Added = v - i - iv + Compensation
0.15

9.00
18.96

18.96

182.76

269.54

86.63

59.64

$-1.44$

13.49

35.22

292.66

161.58

339.93

179.79

134.20

$\begin{array}{rr}-0.39 & -123.6 \% \\ \mathrm{a} & - \\ \mathrm{a} & - \\ 86.19 & 4.3 \% \\ 47.12 & 4.9 \% \\ \mathbf{1 0 5 . 5 0} & \mathbf{6 . 5 \%} \\ \mathbf{5 8 . 7 6} & \mathbf{8 . 2 \%} \\ \mathbf{4 1 . 9 3} & \mathbf{1 0 . 4 \%}\end{array}$

$\begin{array}{rr}-0.13 & -190.5 \% \\ \mathrm{a} & - \\ \mathrm{a} & - \\ 231.46 & -4.1 \% \\ 173.56 & -5.0 \% \\ \mathbf{2 6 2 . 1 9} & \mathbf{- 2 . 7 \%} \\ \mathbf{8 8 . 6 6} & \mathbf{2 . 3 \%} \\ \mathbf{6 2 . 6 0} & \mathbf{5 . 0 \%}\end{array}$

$-0.97$

$32.4 \%$

296.74

29.74
162.29

345.09

183.91

136.93

$-1.55$

10.96

54.98

337.78

214.00

402.18

189.72

143.49

$\begin{array}{rr}-0.56 & 63.6 \% \\ \mathrm{a} & - \\ \mathrm{a} & - \\ 327.13 & -3.2 \% \\ 203.08 & -5.1 \% \\ \mathbf{3 9 4 . 0 7} & \mathbf{- 2 . 0 \%} \\ \mathbf{1 9 1 . 7 5} & \mathbf{1 . 1 \%} \\ \mathbf{1 4 6 . 8 0} & \mathbf{2 . 3 \%}\end{array}$

1.10

14.93

28.21

269.34

132.43

313.59

180.05

125.16

$\begin{array}{rr}1.19 & 8.0 \% \\ \mathrm{a} & - \\ \mathrm{a} & - \\ 258.87 & -3.9 \% \\ 126.58 & -4.4 \% \\ \mathbf{3 2 5 . 8 1} & \mathbf{3 . 9 \%} \\ \mathbf{1 9 7 . 9 7} & \mathbf{1 0 . 0 \%} \\ \mathbf{1 4 5 . 4 1} & \mathbf{1 6 . 2 \%}\end{array}$


j. NAICS 335: Electrical equipment, appliance, \& component mfg

i. Net Inventories Shipped

ii. Depreciation of Capital

iii. Net Income

iv. Expenditures

a. Suppliers of Materials

vi. ASM Value Added = v - i - iv.a + adjustment

k. NAICS 336: Transportation equipment mfg

i. Net Inventories Shipped

ii. Depreciation of Capital

iii. Net Income

iv. Expenditures

a. Suppliers of Materials

$\begin{array}{rr}\text { a } & - \\ \text { a } & - \\ 735.07 & 6.0 \% \\ 538.01 & 6.2 \% \\ \mathbf{8 3 6 . 9 7} & \mathbf{6 . 5 \%} \\ \mathbf{3 0 2 . 1 4} & \mathbf{6 . 1 \%} \\ \mathbf{2 2 6 . 3 6} & \mathbf{5 . 9 \%}\end{array}$

I. NAICS 339: Miscellaneous mfg

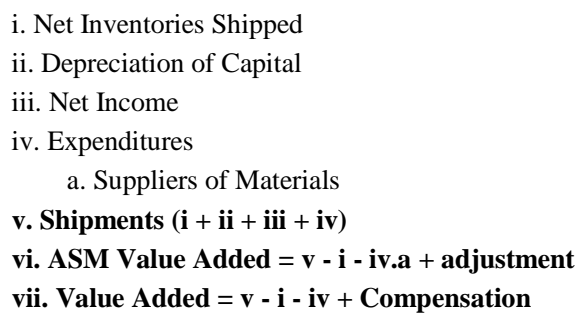

m. Other: Food, apparel, wood product, and printing mfg

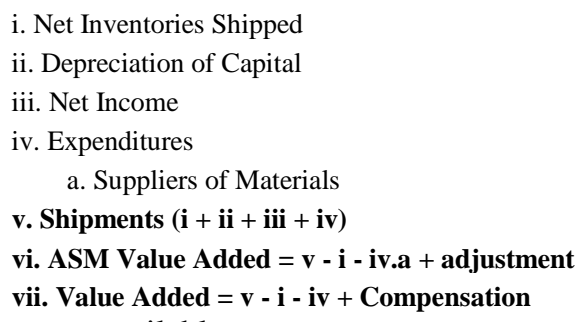

[1] It is adjusted by the addition of value added by merchandising operations plus the net change in finished goods and work-in-process goods.

[2] Compensation includes payroll and fringe benefits (not shown)

traditional method, calculates value added as "gross output (sales or receipts and other operating income, plus inventory change) less intermediate inputs (consumption of goods and services purchased from other industries or imported)." Moreover, the difference is that ASM's calculation of value added includes purchases from other industries such as mining and construction while BEA's does not include it. Table 2-1 has both the ASM's calculation and a calculation that follows the more traditional approach. 
Net income, which could also be referred to as profit, for all manufacturing in 2013 could not be calculated, as the depreciation of capital was not available. The 2012 value was $\$ 781$ billion. Expenditures amounted to $\$ 4746$ billion, resulting in a return on investment of approximately $16.5 \%$. The return on investment in machinery manufacturing (NAICS 333), computer and electronic product manufacturing (NAICS 334), electrical equipment (NAICS 335), and transportation equipment (NAICS 336) was 16.3\%, $10.5 \%, 20.6 \%$, and $10.9 \%$.

In terms of acquisition costs, manufacturing capital (i.e., buildings and machinery) increased $\$ 116$ billion for all of manufacturing, as seen in Table 2-2. In terms of the total value of capital, however, it decreased by $\$ 17$ billion. Net capital acquisitions for machinery, computer and electronics, electrical equipment, and transportation equipment manufacturing increased $\$ 7$ billion, $\$ 14$ billion, $\$ 2$ billion, and $\$ 17$ billion, respectively. The value of capital for machinery and electrical equipment decreased while it increased for computer and electronics and transportation equipment.

Table 2-2: Manufacturing Capital, 2012

\begin{tabular}{|c|c|c|c|c|c|c|c|}
\hline $\begin{array}{l}2012 \\
\text { NAICS } \\
\text { code }\end{array}$ & NAICS Description & $\begin{array}{c}\text { Total capital } \\
\text { expenditures } \\
\text { (\$Billions) }\end{array}$ & $\begin{array}{c}\text { Total } \\
\text { retirements } \\
\text { (acquisition } \\
\text { costs) } \\
\text { (\$Billions) }\end{array}$ & $\begin{array}{c}\text { Gross value } \\
\text { of } \\
\text { depreciable } \\
\text { assets } \\
\text { (acquisition } \\
\text { costs), end } \\
\text { of year } \\
\text { (\$Billions) }\end{array}$ & $\begin{array}{c}\text { Total } \\
\text { depreciation } \\
\text { charges } \\
\text { during year } \\
\text { (\$Billions) }\end{array}$ & $\begin{array}{l}\text { Net Capital } \\
\text { Acquisitions } \\
\text { (\$Billions) }^{*}\end{array}$ & $\begin{array}{l}\text { Change in } \\
\text { value of } \\
\text { capital } \\
\text { (\$Billions) })^{\star *}\end{array}$ \\
\hline $31-33$ & Manufacturing & 164.8 & 49.2 & 2830.4 & 181.9 & 115.5 & -17.1 \\
\hline 311 & Food & 15.4 & 6.0 & 265.8 & 16.4 & 9.3 & -1.0 \\
\hline 312 & Beverage and tobacco & 3.6 & 1.0 & 73.1 & 4.4 & 2.7 & -0.8 \\
\hline 313 & Textile mills & 0.9 & 0.2 & 22.3 & 1.7 & 0.7 & -0.8 \\
\hline 314 & Textile product mills & 0.4 & 0.1 & 11.0 & 0.8 & 0.3 & -0.3 \\
\hline 315 & Apparel & 0.2 & 0.1 & 4.6 & 0.5 & 0.2 & -0.2 \\
\hline 316 & Leather and allied product & 0.1 & 0.0 & 1.9 & 0.1 & 0.1 & 0.0 \\
\hline 321 & Wood product & 2.1 & 1.0 & 54.0 & 3.6 & 1.1 & -1.5 \\
\hline 322 & $\begin{array}{l}\text { Paper } \\
\text { Printing and support }\end{array}$ & 8.0 & 2.0 & 173.2 & 10.7 & 6.0 & -2.6 \\
\hline 323 & activities & 2.5 & 1.3 & 71.0 & 4.9 & 1.2 & -2.4 \\
\hline 324 & Petroleum and coal products & 16.4 & 1.7 & 233.3 & 10.9 & 14.7 & 5.5 \\
\hline 325 & Chemical & 23.1 & 7.2 & 506.0 & 30.2 & 15.9 & -7.1 \\
\hline 326 & Plastics and rubber products & 6.5 & 2.4 & 134.5 & 9.5 & 4.1 & -3.0 \\
\hline 327 & Nonmetallic mineral product & 4.2 & 1.5 & 114.7 & 7.6 & 2.7 & -3.4 \\
\hline 331 & Primary metal & 8.2 & 3.6 & 156.3 & 9.0 & 4.6 & -0.8 \\
\hline 332 & Fabricated metal product & 11.5 & 3.0 & 187.2 & 13.5 & 8.5 & -2.0 \\
\hline 333 & Machinery & 10.5 & 3.2 & 155.8 & 11.0 & 7.4 & -0.4 \\
\hline 334 & Computer and electronics & 19.7 & 5.5 & 204.2 & 14.9 & 14.3 & 4.8 \\
\hline 335 & Electrical equipment & 2.8 & 1.1 & 52.2 & 3.5 & 1.7 & -0.7 \\
\hline 336 & Transportation equipment & 23.2 & 5.8 & 315.0 & 22.1 & 17.4 & 1.1 \\
\hline 337 & Furniture and related & 1.1 & 0.4 & 29.4 & 1.9 & 0.7 & -0.8 \\
\hline 339 & Miscellaneous & 4.4 & 2.1 & 65.0 & 4.9 & 2.2 & -0.6 \\
\hline
\end{tabular}


Bureau of Economic Analysis: The most recent Industry Economic Accounts data (July 2015) from the BEA shows that manufacturing declined by $0.3 \%$ in the first quarter of 2015 to $\$ 1.9$ trillion $^{10}$ and contributed $10.6 \%$ of GDP growth or 0.3 percentage points of GDP growth since the first quarter of $2014 .{ }^{11}$ Approximately $67.6 \%$ of manufacturing growth could be attributed to durable goods manufacturing and $32.4 \%$ could be attributed to nondurable goods manufacturing. As illustrated in Figure 2-5, manufacturing declined significantly in 2008 and has nearly returned to its peak level occurring in 2007. Manufacturing value added declined more than total US GDP, creating a persistent gap. The result is that first quarter GDP is $8.6 \%$ above its peak level while manufacturing is at $0.6 \%$ below its peak level. This is largely driven by nondurable goods manufacturing, which is $7.7 \%$ below its peak occurring in $2007 .{ }^{12}$

Figure 2-6 and Figure 2-7 provide data on durable and nondurable goods. As seen in Figure 2-6, value added for a number of durable goods is higher in 2013 than it was in 2006, including computer and electronic products, machinery, and motor vehicles. As seen in Figure 2-7, in 2013 every category of nondurable goods was below its 2006 value, including chemical manufacturing, petroleum and coal products, and plastics and rubber.

Figure 2-5: Cumulative Percent Change in Value Added (2009 Chained Dollars)

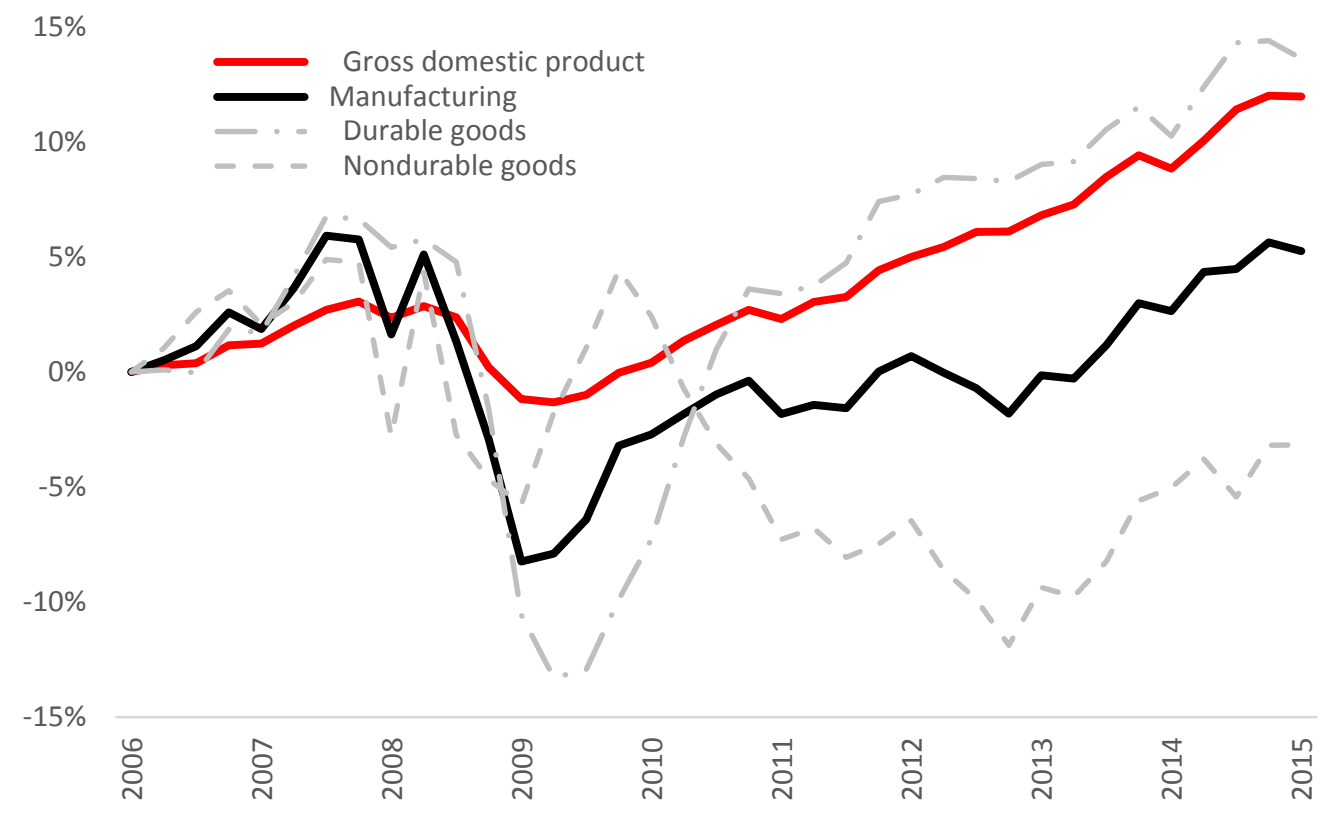

\footnotetext{
${ }^{10}$ Billions of chained dollars seasonally adjusted at annual rates

${ }^{11}$ Growth estimates were made using billions of chained 2009 dollars seasonally adjusted at annual rates.

${ }^{12}$ Bureau of Economic Analysis. "Industry Economic Accounts Data."

$<$ http://www.bea.gov/iTable/index_industry_gdpIndy.cfm>
} 
Figure 2-6: Value Added for Durable Goods by Type, 2006-2013

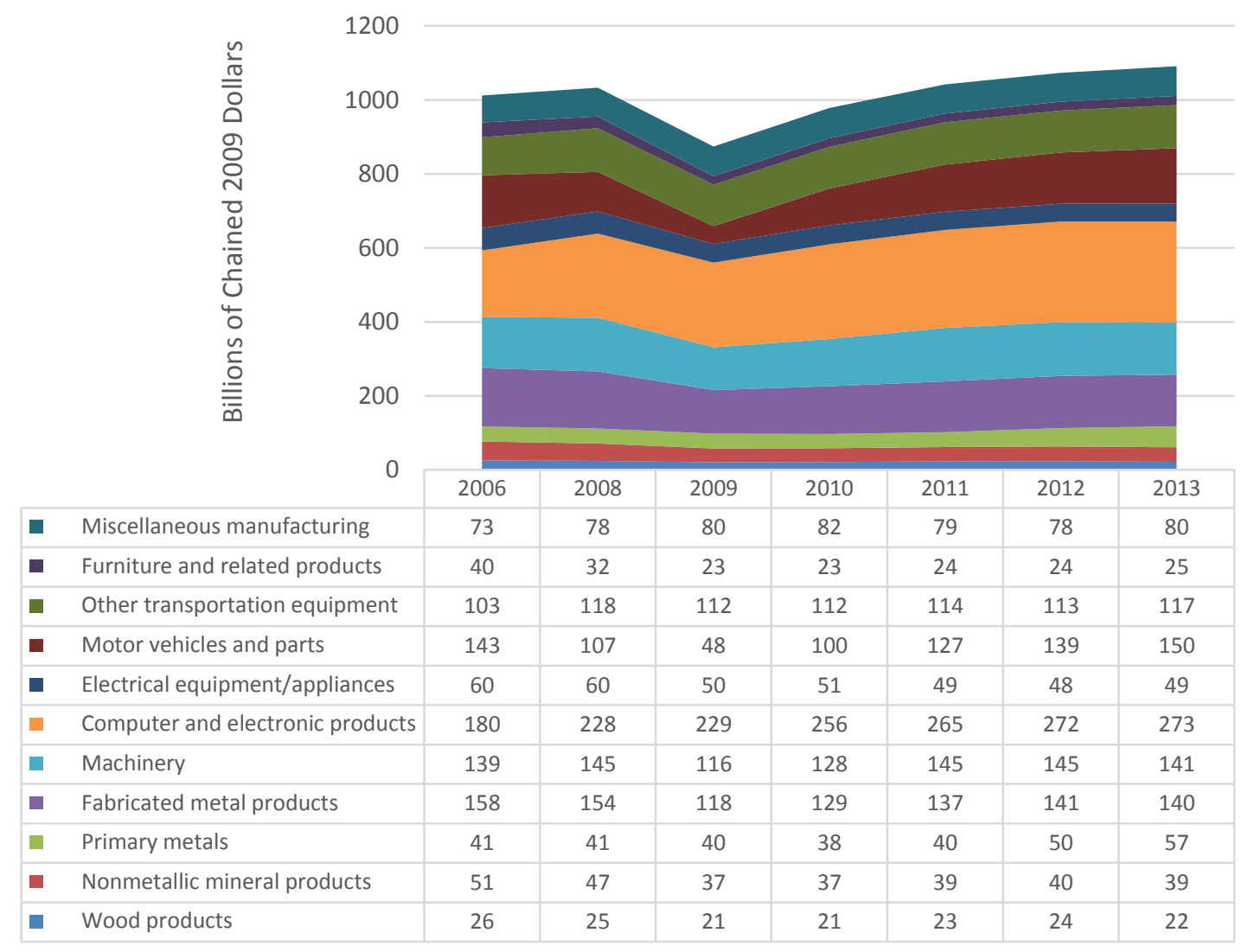

Figure 2-7: Value Added for Nondurable Goods by Type, 2006-2013

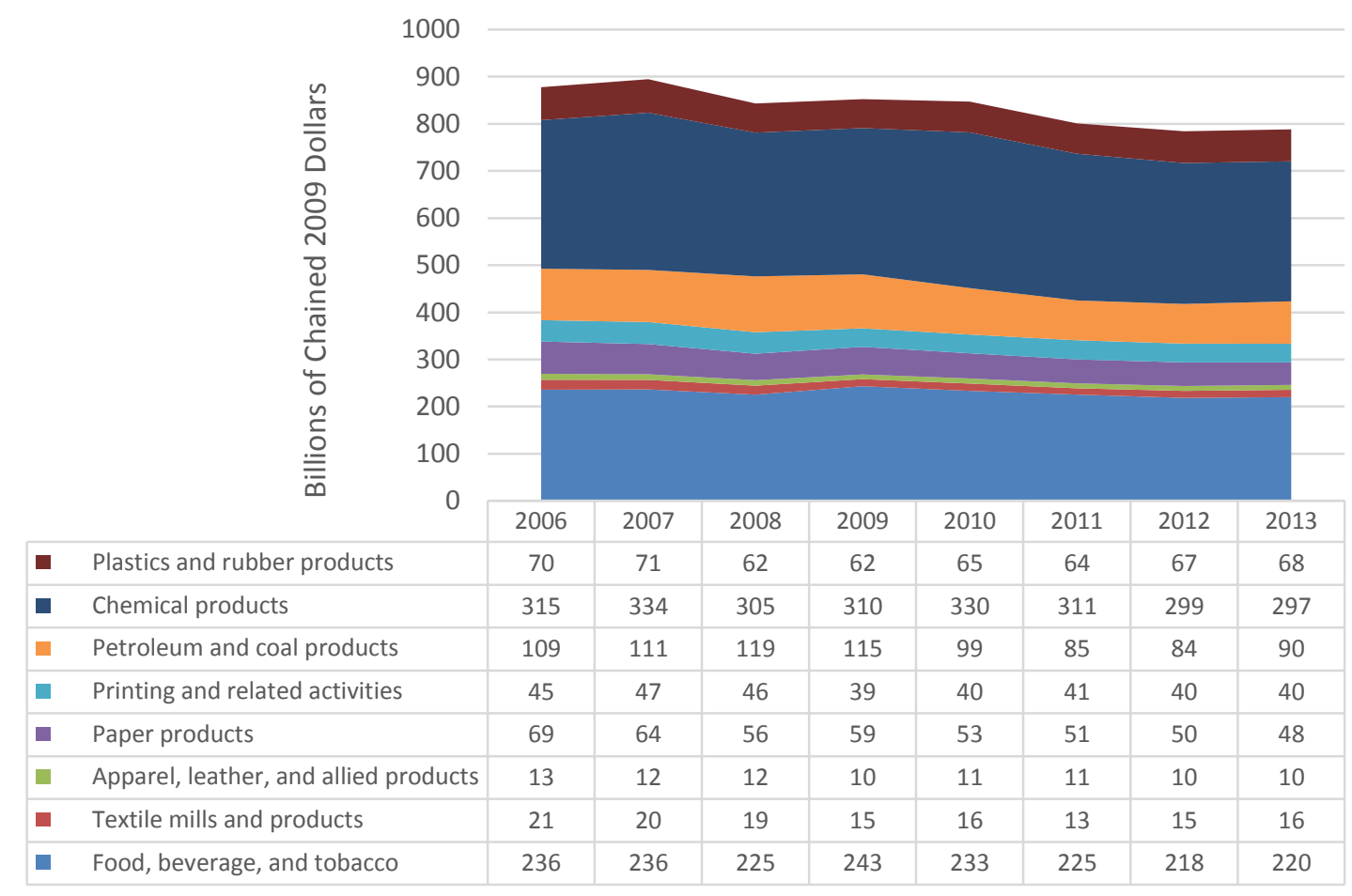


Survey of Plant Capacity Utilization: The Survey of Plant Capacity Utilization reveals the industry's ability to increase value added without increasing the amount of infrastructure needed for production. Even small changes in plant utilization capacity can have large effects on output. Looking at plant capacity utilization statistics for the first quarter of 2015, the time period for which the most recent statistics were available, and focusing on the manufacturing sector defined by NAICS codes 31 through 33, a 69.9\% utilization rate of plant capacity was reported, only slightly changed from the $71.3 \%$ utilization rate reported in the final quarter of 2014.

Digging down deeper into the statistics, we see that the manufacturing of complex durable goods tends to outpace the industry-wide utilization rate for manufacturing. For example, the semiconductor and related device manufacturing has a high utilization rate of $88.7 \%$, automobile manufacturing is at $81.4 \%$, and light truck and utility vehicle management is at $93.7 \%$. Aerospace products and parts manufacturing was at $86.5 \%$. A complex good is defined here as one containing components that are themselves the finished products of other manufacturing processes.

Utilization rates for plants depend on a variety of factors. For example, there might be some change specific to the industry that changes how a plant is utilized. The automobile manufacturing industry has seen many such changes over the last few years due to greater efficiencies in manufacturing sequencing, development of parallel processing, use of quality control processes (e.g. Taguchi methods), and greater use of computer simulations to permit simultaneous multiple part manufacturing under one roof.

Plant capacity utilization rates can also be driven by economic conditions at both the micro and macro level. When the economy is steadily growing, there is greater demand for manufactured products, particularly more complex ones that tend to require more disposable income to purchase. Also, all things being equal, one would expect to see greater plant utilization in industries for which the United States has a relative comparative advantage. However, one should not venture any guesses about why a particular industry has a particular capacity utilization rate without conducting an underlying analysis of both the industry-specific plant characteristics and conditions governing the larger macroeconomic environment. 


\section{Manufacturing Supply Chain}

There are many suppliers of goods and services that have a stake in manufacturing; these include resellers, providers of transportation and warehousing, raw material suppliers, suppliers of intermediate goods, and suppliers of professional services with values from the ASM. ${ }^{13}$ Table 3-1 presents and Figure 3-1 maps, the purchases that the manufacturing industry made for production, which is disaggregated into five categories: suppliers of services, computer hardware, software, and other costs (blue), refuse removal, intermediate goods, and recycling (gold), machinery, structures, and compensation (orange), repair of the machinery and structures (red), and suppliers of materials (green). These items all feed into the design and production of manufactured goods which are inventoried and/or shipped (gray). The depreciation of capital and net income are also included in Figure 3-1, which affects the market value of shipments. In addition to the stakeholders, there are also public vested interests, the end users, and financial service providers.

Table 3-1: Supply Chain Entities and Contributions

$\begin{array}{ccc}2012 & 2013 & \text { Percent } \\ \text { (\$Billions 2012) } & \text { (\$Billions 2013) } & \text { Change }\end{array}$

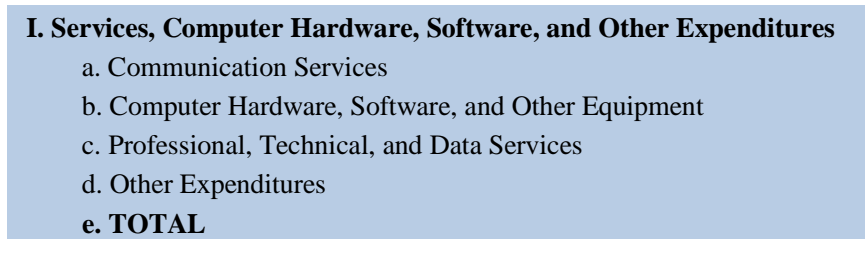

4.52
12.38
36.83
260.94
$\mathbf{3 1 4 . 6 8}$

$\begin{array}{rr}4.78 & 5.7 \% \\ 11.92 & -3.7 \% \\ 35.99 & -2.3 \% \\ 264.62 & 1.4 \% \\ \mathbf{3 1 7 . 3 1} & \mathbf{0 . 8 \%}\end{array}$

$317.31 \quad 0.8 \%$

\begin{tabular}{|c|c|c|c|}
\hline \multicolumn{4}{|l|}{ III. Machinery, Structures, and Compensation Expenditures } \\
\hline a. Payroll, Benefits, and Employment & 773.61 & 789.06 & $2.0 \%$ \\
\hline b. Capital Expenditures: Structures (including rental) & 55.60 & 57.38 & $3.2 \%$ \\
\hline c. Capital Expenditures: Machinery/Equipment (including rental) & 136.94 & 145.71 & $6.4 \%$ \\
\hline d. TOTAL & 966.16 & 992.15 & $2.7 \%$ \\
\hline
\end{tabular}

IV. Suppliers of Materials Expenditures
a. Materials, Parts, Containers, Packaging, etc... Used
3098.56
3135.56
$1.2 \%$
b. Contract Work and Resales
223.31
232.71
$4.2 \%$
c. Purchased Fuels and Electricity
85.19
88.71
$4.1 \%$
d. TOTAL
3407.06
3456.98
$1.5 \%$

\begin{tabular}{|lrrr|}
\hline V. Maintenance and Repair Expenditures & $\mathbf{4 4 . 3 3}$ & $\mathbf{4 6 . 2 2}$ & $\mathbf{4 . 3 \%}$ \\
\hline VI. Shipments & & & \\
a. Expenditures & & 4826.39 & $1.7 \%$ \\
b. Net Inventories Shipped & -11.64 & -8.47 & $27.2 \%$ \\
c. Depreciation & 181.90 & $\mathrm{a}$ & - \\
d. Net Income & 780.68 & $\mathrm{a}$ & - \\
E. TOTAL & $\mathbf{5 6 9 6 . 7 3}$ & $\mathbf{5 8 4 6 . 7 7}$ & $\mathbf{2 . 6 \%}$ \\
\hline
\end{tabular}

a: estimates were unavailable

\footnotetext{
${ }^{13}$ Census Bureau. "Annual Survey of Manufactures.” February 2015. Accessed from the American FactFinder. <http://factfinder.census.gov/faces/nav/jsf/pages/index.xhtml>
} 
Figure 3-1: Manufacturing Supply Chain

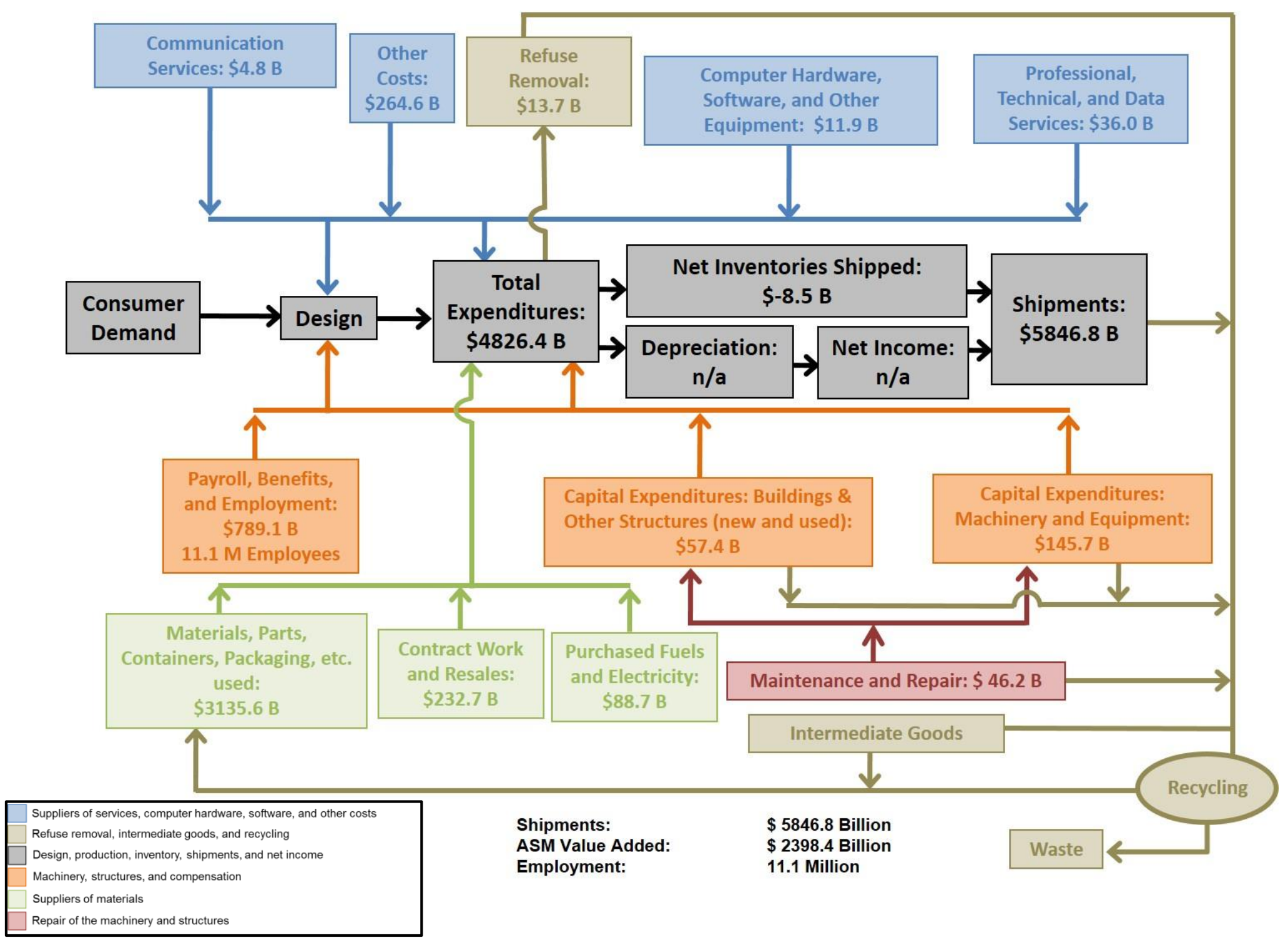




\section{Employment and Compensation}

The Annual Survey of Manufactures estimates that there were 11.1 million employees in manufacturing in 2013, which is the most recent data available (see Table 4-1). The Current Population Survey and Current Employment Statistics have more recent data that estimate that there were 15.1 million and 12.2 million employees in 2013, respectively (see Table 4-2 and Table 4-3). Each of these estimates has its own method for how the data was acquired and its own definition of employment. The Current Population Survey considers an employed person to be any individual who did any work for pay or profit during the survey reference week or were absent from their job because they were ill, on vacation, or taking leave for some other reason. It also includes individuals who completed at least 15 hours of unpaid work in a family-owned enterprise operated by someone in their household. In contrast, the Current Employment Statistics specifically exclude proprietors, self-employed, and unpaid family or volunteer workers; thus, the estimates from the Current Employment Statistics are lower than the Current Population Survey estimates. Additionally, the Current Employment Statistics include temporary and intermittent employees. The Annual Survey of Manufactures considers an employee to include all full-time and part-time employees on the payrolls of operating establishments during any part of the pay period being surveyed excluding temporary staffing obtained through a staffing service. It also excludes proprietors along with partners of unincorporated businesses.

Between 2013 and 2014, manufacturing employment increased $1.6 \%$ according to the Current Population Survey (see Table 4-2) and $1.4 \%$ according to the Current Employment Statistics (see Table 4-3). Meanwhile, total employment increased $1.7 \%$ according to the Current Population Survey (see Table 4-3).

Table 4-1: Employment, Annual Survey of Manufactures

\begin{tabular}{|c|c|c|c|}
\hline & $\begin{array}{c}2012 \\
\text { (employees) }\end{array}$ & $\begin{array}{c}2013 \\
\text { (employees) }\end{array}$ & $\begin{array}{l}\text { Percent } \\
\text { Change }\end{array}$ \\
\hline a. NAICS 324: Petroleum \& coal products mfg & 101209 & 101473 & $0.3 \%$ \\
\hline b. NAICS 325: Chemical mfg & 735553 & 718181 & $-2.4 \%$ \\
\hline c. NAICS 326: Plastics \& rubber products mfg & 699924 & 703688 & $0.5 \%$ \\
\hline d. NAICS 327: Nonmetallic mineral product mfg & 352424 & 348434 & $-1.1 \%$ \\
\hline e. NAICS 331: Primary metal mfg & 392495 & 386251 & $-1.6 \%$ \\
\hline f. NAICS 332: Fabricated metal product mfg & 1388550 & 1379859 & $-0.6 \%$ \\
\hline g. NAICS 333: Machinery mfg & 1055375 & 1057684 & $0.2 \%$ \\
\hline h. NAICS 334: Computer \& electronic product mfg & 856725 & 811598 & $-5.3 \%$ \\
\hline i. NAICS 335: Electrical equipment \& component mfg & 337672 & 332176 & $-1.6 \%$ \\
\hline j. NAICS 336: Transportation equipment mfg & 1357124 & 1383528 & $1.9 \%$ \\
\hline k. NAICS 339: Miscellaneous mfg & 546814 & 537021 & $-1.8 \%$ \\
\hline 1. Other: Food, apparel, wood product, and printing mfg & 3390303 & 3322343 & $-2.0 \%$ \\
\hline J. TOTAL MANUFACTURING & 11214165 & 11082237 & $-1.2 \%$ \\
\hline
\end{tabular}


Table 4-2: Employment by Industry for 2013 and 2014 (Thousands): Current Population Survey

\begin{tabular}{|c|c|c|c|c|}
\hline Industry & $\begin{array}{c}\text { Total Employed } \\
2013\end{array}$ & $\begin{array}{c}\text { Total Employed } \\
2014\end{array}$ & $\begin{array}{c}\text { Employment } \\
\text { Change }\end{array}$ & $\begin{array}{l}\text { Percent } \\
\text { Change }\end{array}$ \\
\hline Mining & 1065 & 1088 & 23 & $2.2 \%$ \\
\hline Construction & 9271 & 9813 & 542 & $5.8 \%$ \\
\hline Manufacturing & 14869 & 15100 & 231 & $1.6 \%$ \\
\hline Wholesale and Retail Trade & 19653 & 20251 & 598 & $3.0 \%$ \\
\hline Transportation and Utilities & 7415 & 7581 & 166 & $2.2 \%$ \\
\hline Information & 2960 & 3115 & 155 & $5.2 \%$ \\
\hline Financial Activities & 9849 & 9871 & 22 & $0.2 \%$ \\
\hline Professional and Business Services & 16793 & 17004 & 211 & $1.3 \%$ \\
\hline Education and Health Services & 32535 & 32830 & 295 & $0.9 \%$ \\
\hline Leisure and Hospitality & 13554 & 13489 & -65 & $-0.5 \%$ \\
\hline Other Services & 7127 & 7169 & 42 & $0.6 \%$ \\
\hline Public Administration & 6708 & 6757 & 49 & $0.7 \%$ \\
\hline Agriculture & 2130 & 2237 & 107 & $5.0 \%$ \\
\hline TOTAL * & 143929 & 146305 & 2376 & $1.7 \%$ \\
\hline
\end{tabular}

Table 4-3: Manufacturing Employment (Thousands): Current Employment Statistics

\begin{tabular}{lccc} 
& 2013 & 2014 & Percent Change \\
\hline Manufacturing & 12020 & 12188 & $1.4 \%$ \\
Durable Goods & 7548 & 7685 & $1.8 \%$ \\
Nondurable Goods & 4472 & 4503 & $0.7 \%$ \\
\hline
\end{tabular}

Source: Bureau of Labor Statistics. Current Employment Statistics.

http://www.bls.gov/ces/home.htm

Between January of 2006 and January of 2010, manufacturing employment declined by $19.4 \%$, as seen in Figure 4-1. As of August 2015, employment is still $13.2 \%$ below its 2006 level. In times of financial difficulty, large purchases are often delayed or determined to be unnecessary. Thus, it would be expected that during the recent recession durable goods would decline more than nondurable goods. As can be seen in the Figure 4-1, durable goods declined more than manufacturing as a whole while nondurable goods did not decline as much. By January of 2010, durable goods had declined $22.2 \%$ while nondurables declined $14.5 \%$. As of August of 2013, durables was $13.3 \%$ below its 2006 levels while nondurables was at $13.2 \%$. 
Figure 4-1: Cumulative Change in Percent in Manufacturing Employment (Seasonally Adjusted), 2006-2014

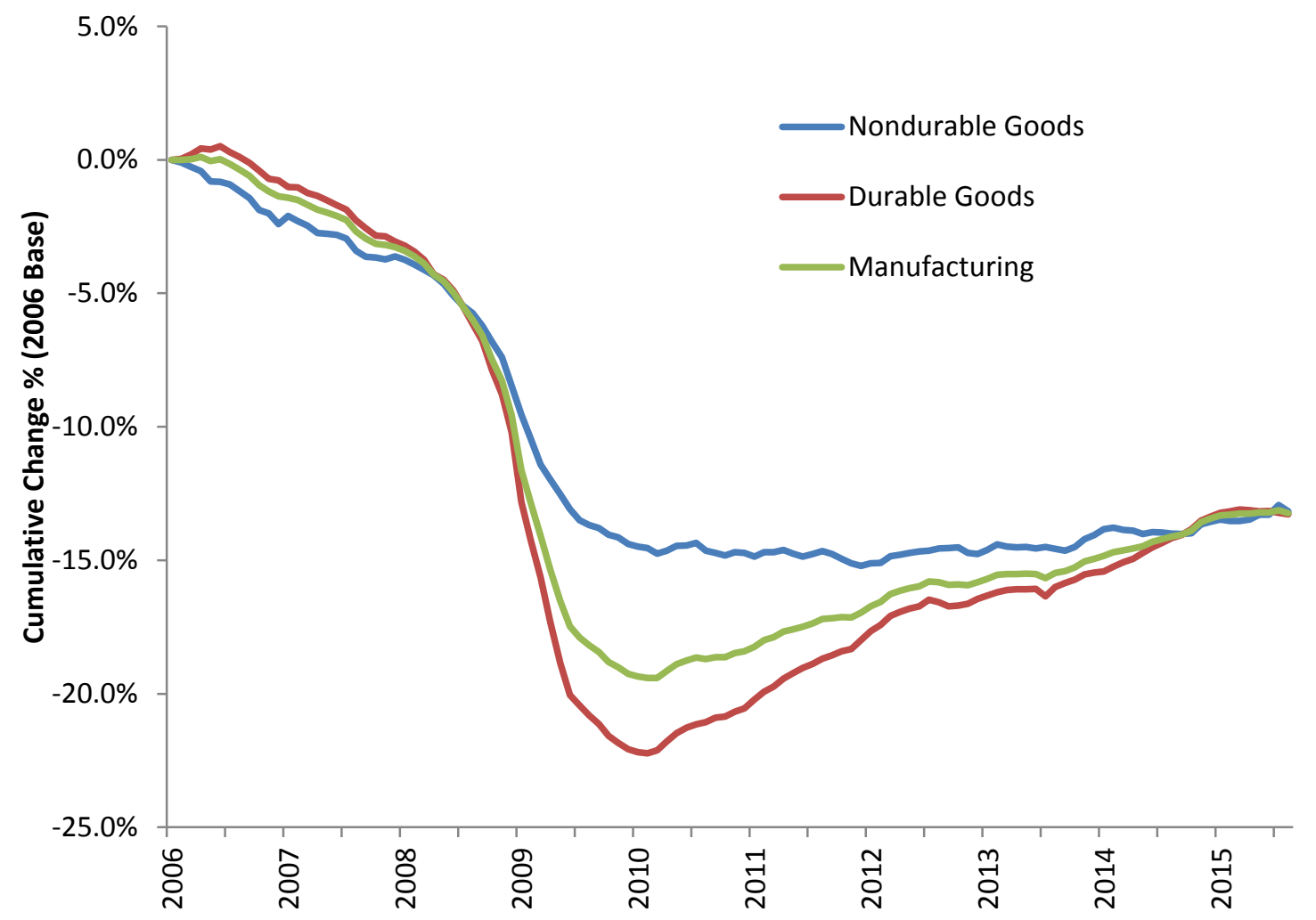

The employees that work in manufacturing sacrifice their time and, in some cases, their safety in return for compensation. In terms of safety, the number of fatal injuries decreased between 2012 and 2013 (see Table 4-4). Nonfatal injuries and the injury rate has decreased as well (see Table 4-5). However, the incident rate for nonfatal injuries in manufacturing remains higher than that for all private industry. During the recession, the number of hours worked per week declined, as seen in Figure 4-2. Unlike employment, however, the number of hours worked per week returned to its pre-recession levels or slightly higher. Average wages increased significantly during the recession and decreased during the following recovery, as can be seen in Figure 4-3. This is likely because low wage earners are disproportionately impacted by employment reductions, which suggests that high wage earners not only receive more pay, they also have more job security. 
Table 4-4: Fatal Occupational Injuries by Event or Exposure

\begin{tabular}{|c|c|c|c|c|c|c|c|c|}
\hline & & Total & $\begin{array}{l}\text { Violence and } \\
\text { other injuries } \\
\text { by persons or } \\
\text { animals }\end{array}$ & $\begin{array}{l}\text { Transportation } \\
\text { Incidents }\end{array}$ & $\begin{array}{c}\text { fires and } \\
\text { explosions }\end{array}$ & $\begin{array}{c}\text { Falls, } \\
\text { slips, } \\
\text { trips }\end{array}$ & $\begin{array}{l}\text { exposure to } \\
\text { harmful sub- } \\
\text { stances or } \\
\text { environments }\end{array}$ & $\begin{array}{c}\text { Contact } \\
\text { with } \\
\text { objects and } \\
\text { equipment }\end{array}$ \\
\hline \multirow{2}{*}{ 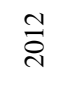 } & Total & 4628 & 803 & 1923 & 122 & 704 & 340 & 723 \\
\hline & Manufacturing & 327 & 45 & 87 & 25 & 39 & 28 & 102 \\
\hline \multirow{2}{*}{$\stackrel{m}{\infty}$} & Total & 4585 & 773 & 1865 & 149 & 724 & 335 & 721 \\
\hline & Manufacturing & 312 & 36 & 91 & 12 & 42 & 18 & 110 \\
\hline \multirow{2}{*}{ 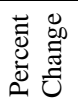 } & Total Private Industry & $-0.9 \%$ & $-3.7 \%$ & $-3.0 \%$ & $22.1 \%$ & $2.8 \%$ & $-1.5 \%$ & $-0.3 \%$ \\
\hline & Manufacturing & $-4.6 \%$ & $-20.0 \%$ & $4.6 \%$ & $-52.0 \%$ & $7.7 \%$ & $-35.7 \%$ & $7.8 \%$ \\
\hline
\end{tabular}

Source: Bureau of Labor Statistics. Census of Fatal Occupational Injuries. "Industry by Event or Exposure."

<http://stats.bls.gov/iif/oshcfoil.htm>

Table 4-5: Total Recordable Cases of Nonfatal Injuries and Illnesses, Private Industry

\begin{tabular}{|c|c|c|c|c|}
\hline \multirow{3}{*}{ 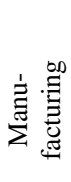 } & & 2012 & 2013 & Percent Change \\
\hline & $\begin{array}{l}\text { Incident Rate per } 100 \text { full time } \\
\text { workers }\end{array}$ & 4.2 & 4.0 & $-4.8 \%$ \\
\hline & $\begin{array}{l}\text { Total Recordable Cases } \\
\text { (thousands) }\end{array}$ & 503.8 & 476.7 & $-5.4 \%$ \\
\hline 䒕 & $\begin{array}{l}\text { Incident Rate per } 100 \text { full time } \\
\text { workers }\end{array}$ & 3.4 & 3.3 & $-2.9 \%$ \\
\hline 㞯 & $\begin{array}{l}\text { Total Recordable Cases } \\
\text { (thousands) }\end{array}$ & 3027.6 & 3007.3 & $-0.7 \%$ \\
\hline
\end{tabular}

Source: Bureau of Labor Statistics. Injuries, Illness, and Fatalities Program. 2010-

2011. http://www.bls.gov/iif/ 
Figure 4-2: Hours Worked per Week

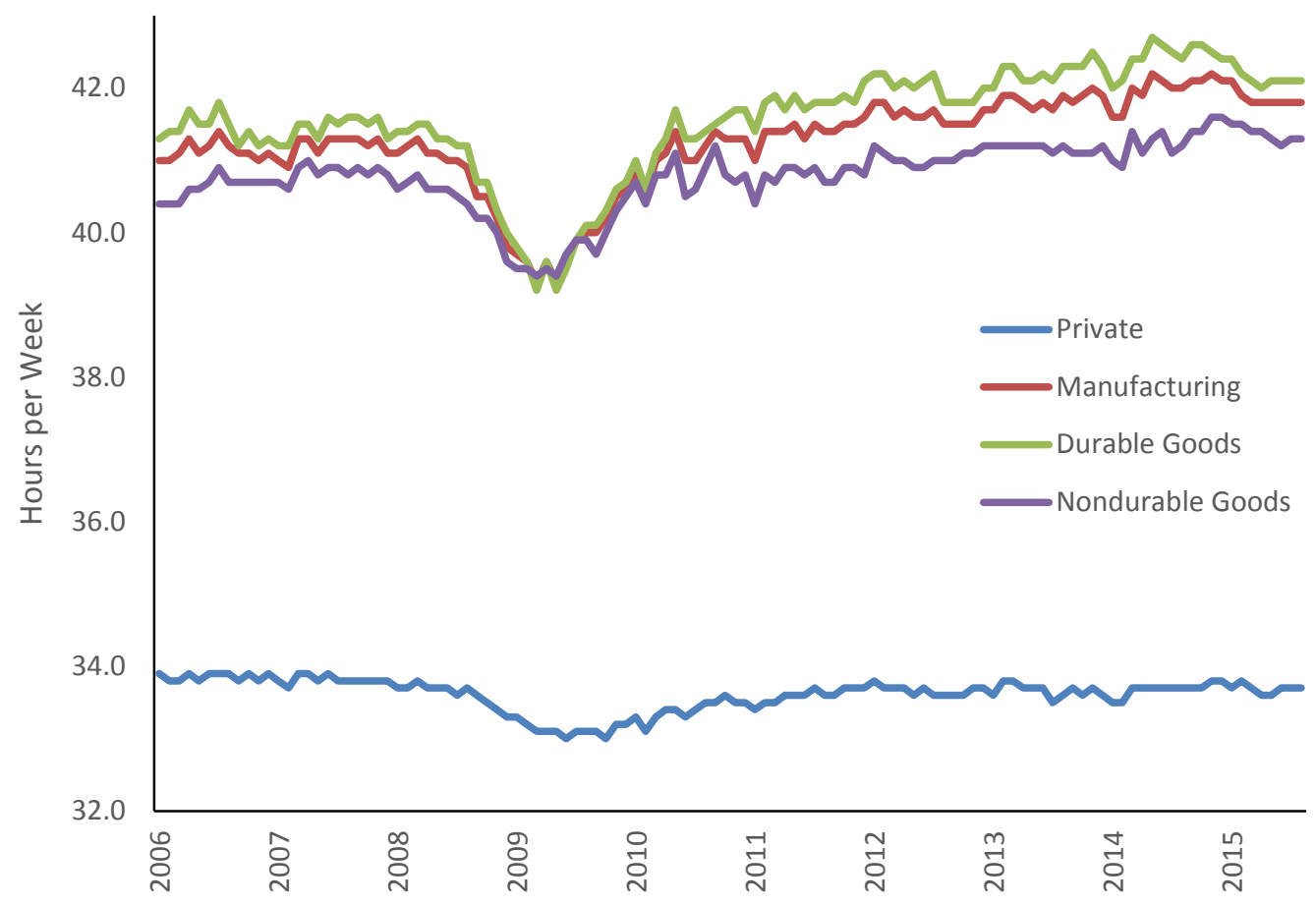

Source: Bureau of Labor Statistics. Current Employment Statistics. <http://www.bls.gov/ces/home.htm〉

Figure 4-3: Wages for Manufacturing and Private Industry

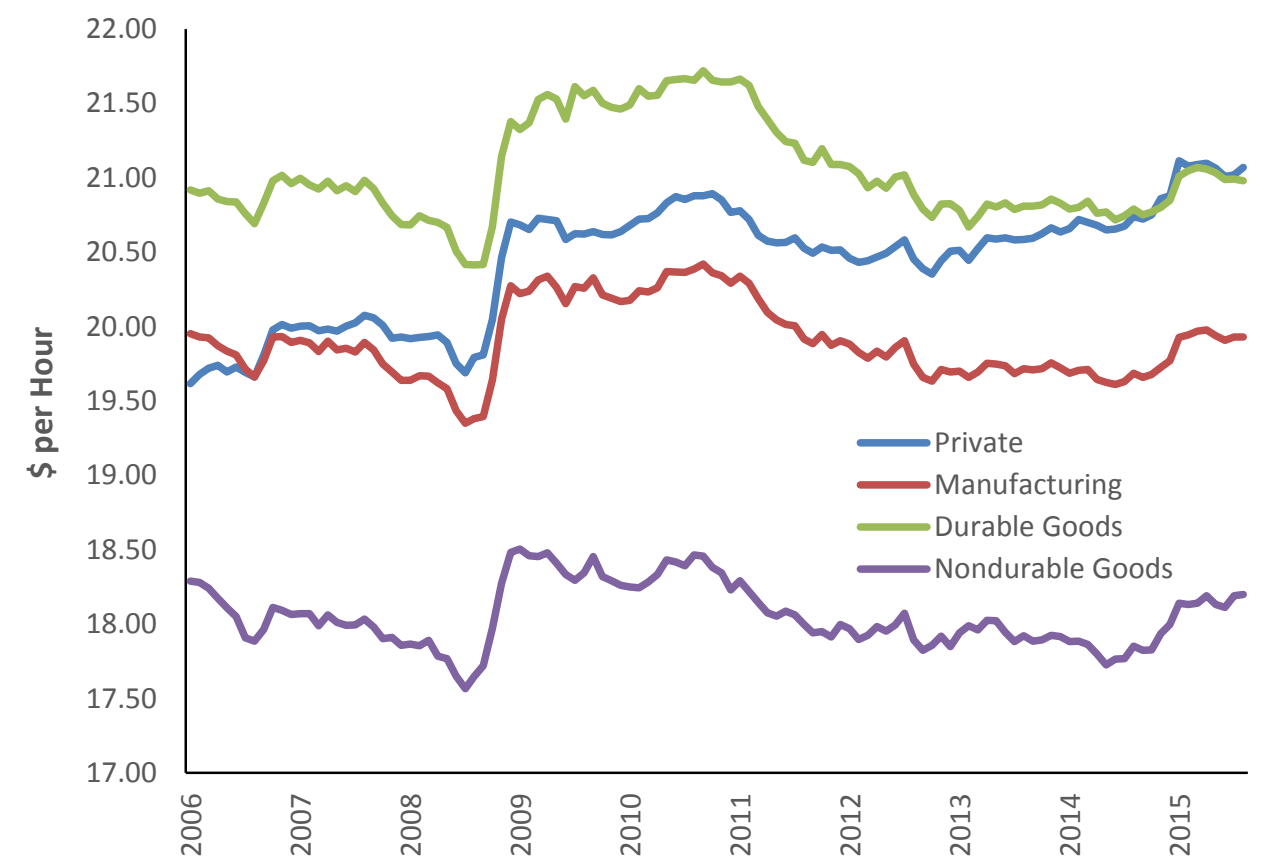

Source: Bureau of Labor Statistics. Current Employment Statistics. <http://www.bls.gov/ces/home.htm> 


\section{Discussion}

This report provides an overview of the US manufacturing industry. There are three aspects of U.S. manufacturing that are considered: (1) how the US industry compares to other countries, (2) the trends in the domestic industry, and (3) the industry trends compared to other country's trends. According to the 2013 Annual Survey of Manufactures (ASM), the US manufacturing sector produced \$2.4 trillion in value added in 2013 , up $4.2 \%$ from $\$ 2.3$ trillion in 2012 . Value added in machinery manufacturing (North American Industry Classification System code (NAICS) 333), computer and electronic product manufacturing (NAICS 334), electrical equipment (NAICS 335), and transportation equipment (NAICS 336) grew $1.1 \%, 10.0 \%, 0.0 \%$, and $6.1 \%$, respectively. According to data from the United Nations Statistics Division, US compound annual real (controlling for inflation) growth between 1988 and 2013 was $2.2 \%$. This puts the US in the $47^{\text {th }}$ percentile of all countries. This growth exceeded that of Germany, France, Canada, Japan, and Australia; however, it is slower than the global average and that of many emerging economies. The size of the US manufacturing industry, as measured in value added, remains the largest of all countries. Among the ten largest manufacturing countries, the US has the $4^{\text {th }}$ largest manufacturing value added per capita.

In addition to the data on past activities in manufacturing, some entities work toward forecasting future activities. The Manufacturers Alliance for Productivity and Innovation (MAPI), a large alliance of various manufacturing concerns, makes widely followed predictions on the growth or contraction of the manufacturing industry. For 2015, it forecasts a $2.5 \%$ growth rate in the manufacturing industry as compared to a 3.5\% growth rate in 2014. MAPI believes there will be a slowdown from last year's manufacturing growth rate because of the drawn-out economic recovery (which they attribute in part to weather fluctuations), which has seen smaller growth in consumer demand. MAPI also believes that the consumers are using any extra income they are earning (or receiving from wider economic trends like the collapse in oil prices) to pay down current debt instead of consuming manufactured goods. This creates a ripple effect in the wider U.S. manufacturing industry that leads to less-than-robust demand in the near future. 


\section{Bibliography}

Bureau of Economic Analysis. "Industry Economic Accounts Data." <http://www.bea.gov/iTable/index_industry_gdpIndy.cfm>

Bureau of Labor Statistics. Current Employment Statistics. <http://www.bls.gov/ces/home.htm>

Bureau of Labor Statistics. Census of Fatal Occupational Injuries. "Industry by Event or Exposure." <http://stats.bls.gov/iif/oshcfoi1.htm>

Bureau of Labor Statistics. Injuries, Illness, and Fatalities Program. 2010-2011. http://www.bls.gov/iif/

Callen, Tim. March 2007. PPP Versus the Market: Which Weight Matters? Finance and Development. Vol 44 number 1.

<http://www.imf.org/external/pubs/ft/fandd/2007/03/basics.htm>

Census Bureau. "Annual Survey of Manufactures." February 2015. Accessed from the American FactFinder. <http://factfinder.census.gov/faces/nav/jsf/pages/index.xhtml>

Census Bureau. "Economic Census.” March 2015. Accessed from the American

FactFinder. <http://factfinder.census.gov/faces/nav/jsf/pages/index.xhtml>

Current Population Survey, Bureau of Labor Statistics. "Table 17: Employed Persons by Industry, Sex, Race, and Occupation." <http://www.bls.gov/cps>Dornbusch, Rudiger, Stanley Fischer, adn Richard Startz. 2000. Macroeconomics. 8th ed. London, UK: McGraw-Hill.

Thomas, Douglas S. The Current State and Recent Trends of the US Manufacturing Industry. NIST Special Publication 1142. <http://nvlpubs.nist.gov/nistpubs/SpecialPublications/NIST.SP.1142.pdf>

Thomas, Douglas S. The US Manufacturing Value Chain: An International Perspective. February 2014. NIST Technical Note 1810.

<http://www.nist.gov/customcf/get_pdf.cfm?pub_id=914022>

United Nations Statistics Division. "National Accounts Main Aggregates Database." $<$ http://unstats.un.org/unsd/snaama/Introduction.asp> 